\title{
Sledging injuries in the fens: an unlikely epidemic?
}

\author{
P.G. Chapman FRCS, B. Cohen* FRCS and D. J. Shewring* FRCS
}

West Suffolk Hospital, Bury St. Edmonds and *Department of Orthopaedic and Trauma Surgery, Addenbrooke's Hospital, Cambridge CB2 2QQ, UK

There have been intermittent reports of injuries associated with the pastime or sport of sledging ${ }^{1,2}$. Significant snowfalls are relatively rare in this part of Great Britain, but when the snow does fall people gather at appropriate inclines keen to slide down on a variety of sledges, tin trays, plastic bags or in some cases nothing at all (Figures 1 and 2).

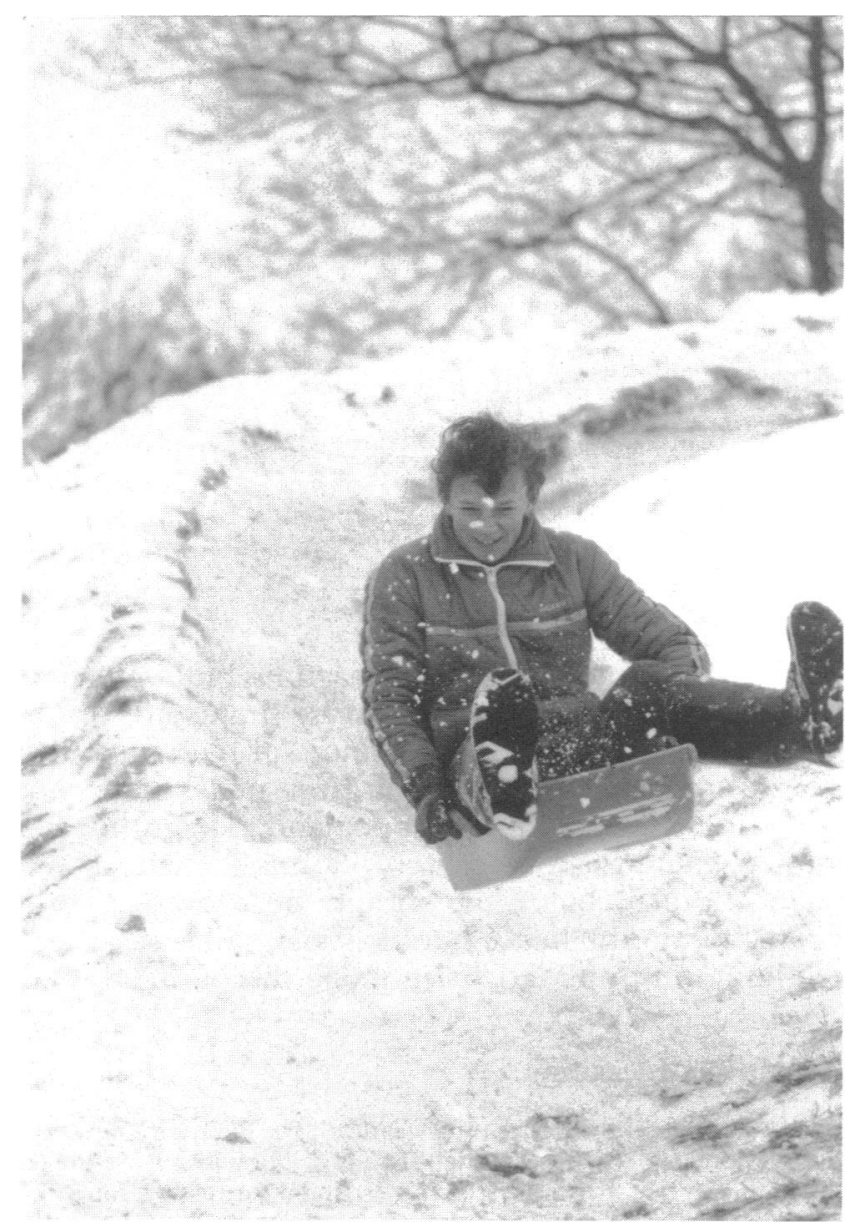

Figure 1. Sledging

Address for correspondence: Mr P.G. Chapman, West Suffolk Hospital, Hardwick Lane, Bury St. Edmonds IP33 2QZ, UK (C) 1991 Butterworth-Heinemann Ltd. 0306-3674/91/030129-02

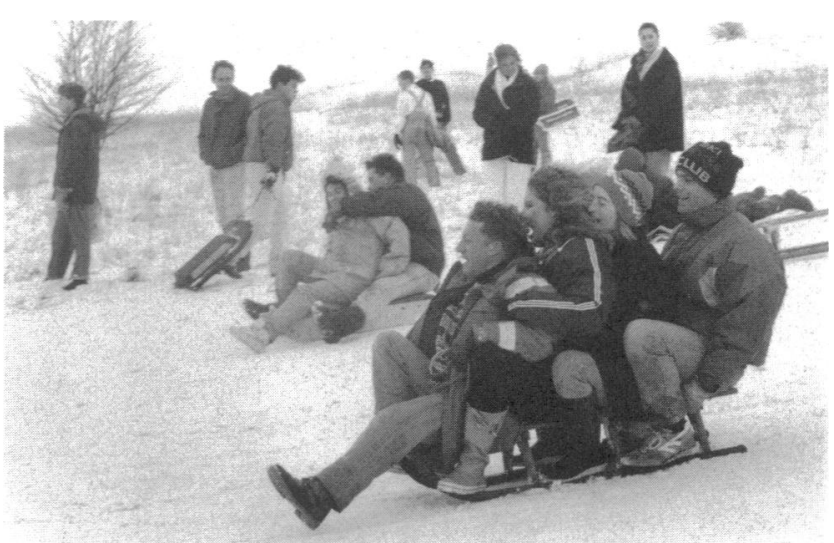

Figure 2. Sledging

\section{Methods and results}

All the injuries sustained whilst sledging during a spell of heavy snow between February 6 and 15, 1991 were recorded retrospectively by reviewing the accident cards of all patients attending the accident service in the hospital during this period. There were 35 patients attending with sledging injuries during this period. Their age and sex distribution are shown in Table 1.

We recorded 39 separate injuries in 35 patients. These are detailed in Table 2.

Some of the injuries were sustained whilst using articles not designed as sledges, or in two cases no sledge at all. In no case was protective clothing worn. Only five of our series (14\%) sustained their injury as

Table 1. Age and sex distribution of 35 patients

\begin{tabular}{lll}
\hline & \multicolumn{2}{c}{ Age in years } \\
\cline { 2 - 3 } & Mean(s.d.) & Range \\
\hline All patients $(n=35)$ & $17.9(10.7)$ & $7-53$ \\
Males $(n=24)$ & $19.0(12.4)$ & $7-53$ \\
Females $(n=11)$ & $15.5(5.4)$ & $8-23$ \\
\hline
\end{tabular}




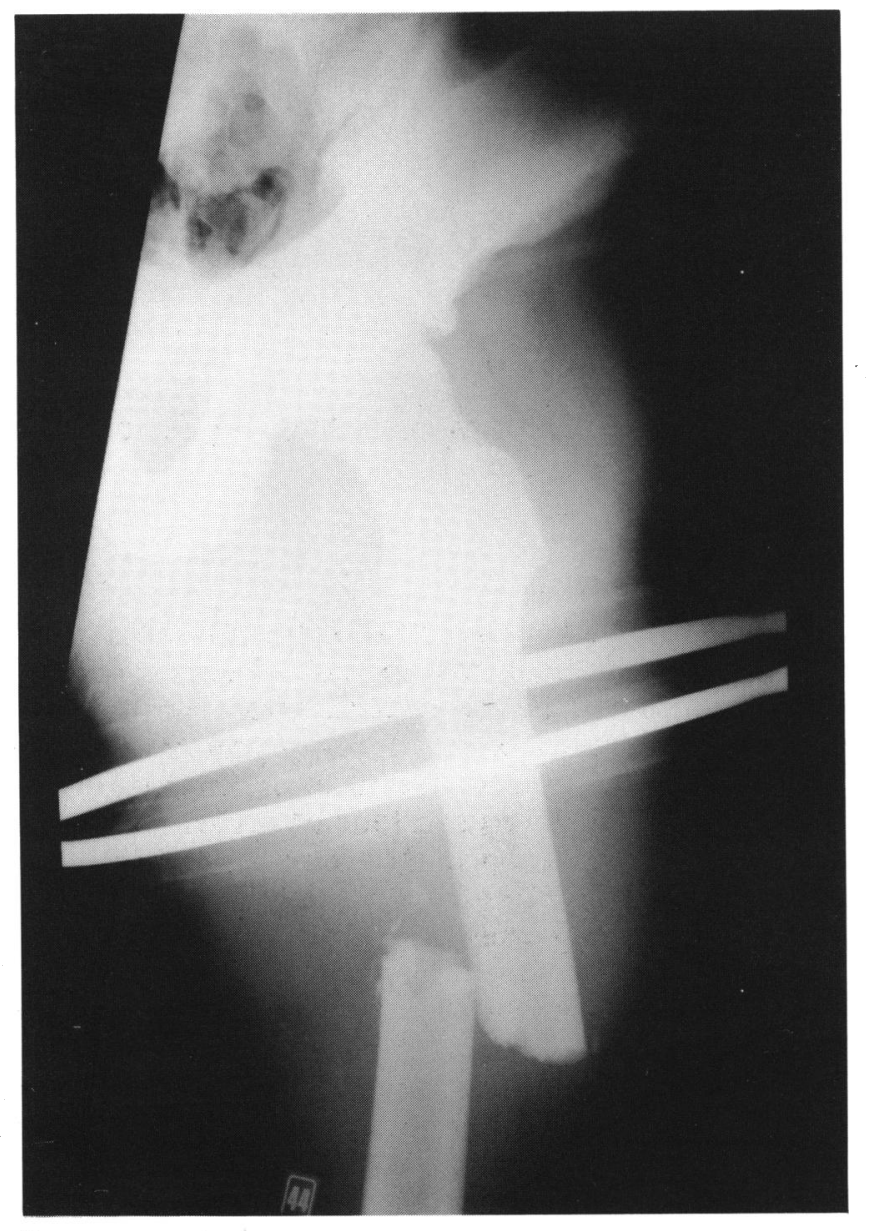

a

Figure 3. Compound femoral fracture $\mathbf{a}$ before and $\mathbf{b}$ after internal fixation

'pedestrians' - hit by a sledge - which is a smaller percentage than that recorded by Sloan et al. ${ }^{2}$

In one accident, two youths were injured whilst being towed on a fibreglass skylight along the road at $20 \mathrm{mph}$ by a van. They struck an oncoming vehicle sustaining in one case a compound femoral fracture (Figure $3 a$ and $b$ ), and in the other a fractured pelvis.

Table 2. Distribution and type of injuries

\begin{tabular}{lcl}
\hline Location & No. & \multicolumn{1}{c}{ Type } \\
\hline Upper limb & 14 & $\begin{array}{l}\text { Five soft tissue injuries } \\
\text { Nine fractures } \\
\text { Eight soft tissue injuries } \\
\text { Seven fractures } \\
\text { Two lacerations } \\
\text { Two closed head injuries }\end{array}$ \\
Head and neck & 17 & $\begin{array}{l}\text { Two lacerations } \\
\text { Three bruised backs } \\
\text { One fractured pelvis }\end{array}$ \\
\hline
\end{tabular}

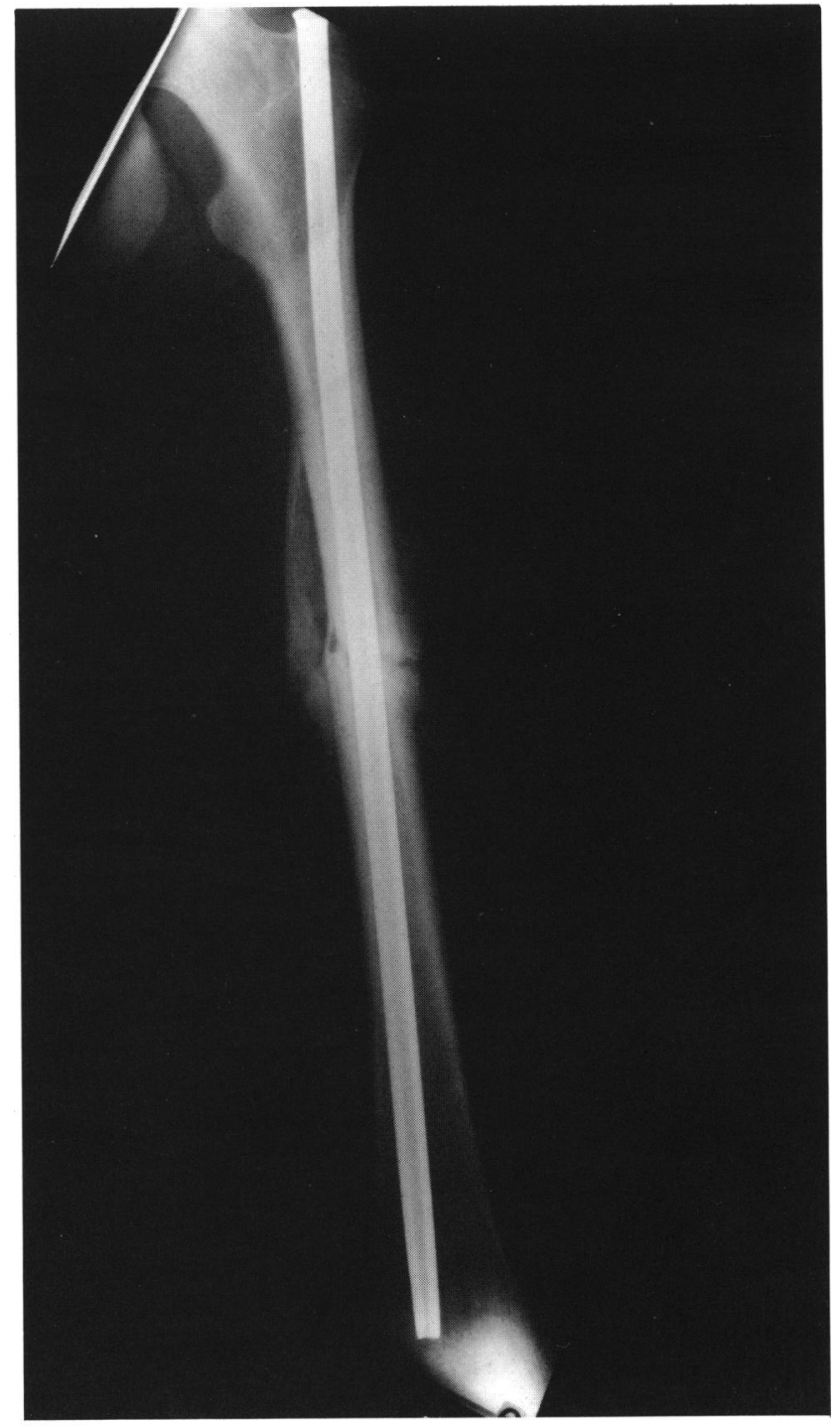

b

\section{Discussion}

Sledging can be a dangerous pastime but we believe that its safety can be improved by the use of proper equipment and the observance of certain rules. 'Runs' should be cordoned off from pedestrians, and use should be made of proper and not improvised equipment. Adequate safety clothing such as that used for skateboarding should be worn, offering protection to the head, hands, wrist, ankles and feet. Sledging on public roads must be discouraged.

\section{Acknowledgements}

The authors acknowledge the Cambridge Evening News for permission to reproduce the sledging photograph, and the Accident Service of Addenbrooke's Hospital for help in retrieving records.

\section{References}

1 Hedges JR, Greenberg MI. Sledding Injuries. Ann Emerg Med 1980; 9: 131-3.

2 Sloan JP, Maheson M, Dove AF. How dangerous is sledging? $\mathrm{Br}$ Med J 1985; 290: 821. 